\title{
IMPLEMENTASI CARD DALAM PERANCANGAN PROGRAM BANTU PEMBELAJARAN MEMBACA
}

\author{
Nanik Triastuti, Lucia Dwi Krisnawati, Andronicus Riyono \\ Fakultas Teknologi Informasi Program Studi Teknik Informatika \\ Universitas Kristen Duta Wacana Yogyakarta \\ Email: 22064125@students.ukdw.ac.id, krisna@ukdw.ac.id, riyono@gmail.com
}

\begin{abstract}
Abstrak :
Pada saat ini, komputer merupakan media yang banyak digunakan untuk berbagai macam bidang seperti perbankan, keuangan, manajemen dan bahkan pendidikan. Pemanfaatan teknologi ini sangat baik digunakan untuk anak-anak tetapi masih belum banyak yang memenuhi kebutuhan anak penyandang cacat. Pemanfaatan teknologi komputer digunakan untuk mengembangkan aplikasi program bantu pembelajaran yang memiliki antarmuka yang baik dan mudah dipahami oleh anak dengan kebutuhan khusus. Perancangan dan pengembangan aplikasi dilakukan dengan metode Collaborative Analysis of Requirement and Design (CARD). Kesimpulan yang diperoleh berdasarkan penelitian dan pengujian antarmuka aplikasi kepada pengguna menunjukkan bahwa penerapan metode CARD dalam pengembangan aplikasi program bantu pembelajaran membaca dapat menghasilkan antarmuka yang baik bagi pengguna dengan kebutuhan khusus. Hal ini ditunjukan dengan tingkat keberhasilan sistem yang mencapai $79,26 \%$ dengan hasil uji preferensi sebesar $60 \%$ menyatakan aplikasi program bantu pembelajaran membaca baik bagi pengguna dengan kebutuhan khusus. Antarmuka aplikasi ini memberikan pemahaman yang baik dan memberikan kemudahan bagi pengguna dengan kebutuhan khusus dalam menggunakan aplikasi tersebut.
\end{abstract}

Kata Kunci : Metode CARD, antarmuka pengguna,pembelajaran membaca

\section{Pendahuluan}

Teknologi informasi sekarang ini tidak hanya dimanfaatkan oleh orang dewasa saja tetapi juga anak-anak. Penggunaan komputer bagi orang dewasa memberikan manfaat yang besar di berbagai bidang seperti di bidang keuangan, manajemen dan perbankan, bahkan dimanfaatkan di bidang pendidikan bagi anak-anak. Pemanfaatan ini dirasa masih belum maksimal terutama pendidikan bagi anak-anak yang memiliki kebutuhan khusus (difable).

Kemampuan anak-anak difable untuk menerima pelajaran, mengingat dan memahami pelajaran sangat kurang. Dibutuhkan kesabaran dan kreatifitas dari tenaga pengajar untuk mengajar anak-anak difable. 
Oleh karena itu akan dikembangkan rekayasa perangkat lunak pembelajaran yang membantu mengatasi permasalahan tersebut. Dengan pemanfaatan teknologi animasi yang interaktif diharapkan dapat membangun aplikasi dengan antarmuka yang memberikan kemudahan dan daya tarik dalam proses pembelajaran. Perangkat lunak pembelajaran hanyalah sarana saja, sedangkan fungsi utama pengajaran tetap berada di tangan tenaga pengajar.

\section{Tinjauan Pustaka}

\subsection{Card Sorting}

Menurut Barrett dan Edwards (1996) card sorting adalah metode/teknik yang baik untuk pengumpulan informasi (knowledge elicitation), dan telah digunakan secara luas dalam berbagai bidang ilmu seperti psikologi, Knowledge Engineering, Software Engineering dan Web Site Design. Dalam teknik pengumpulan persyaratan, metode card sorting merupakan metode yang baik dalam pengumpulan persyaratan (Maiden \& Rugg, 1996). Selain merupakan teknik yang baik dalam proses pengumpulan informasi dan klasifikasi, metode card sorting juga merupakan metode yang dapat digunakan untuk mengetahui pola pikir pengguna (Nielsen \& Sano, 1995).

Setelah pengumpulan dan klasifikasi data, metode card sorting dapat pula di implemetasikan dalam pengurutan informasi secara terstruktur dalam bagian-bagian yang lebih spesifik (Cavusoglu et al., 2004) sehingga sangat membantu dalam mengelola bagian-bagian informasi atau konsep sebuah aplikasi (Faiks \& Hyland, 2000).

Dalam sebuah penelitian yang dilakukan oleh Paul Eccleson dan Christoph Jakfeld (1992) metode card sorting digunakan untuk merancang sebuah sistem manajemen informasi yang mampu melakukan pelayanan langsung terhadap konsumen. Card sorting digunakan dalam pembuatan basis pengetahuan tim manajemen pemesanan di Computer Peripheral Bristol (CPB). Aktivitas card sorting digunakan untuk menemukan aturan contoh pemesanan.

Yang dilakukan adalah mengumpulkan informasi dari setiap anggota tim manajemen pemesanan untuk menafsirkan atribut apa yang mereka gunakan untuk menentukan prioritas pemesanan. Kemudian dilakukan sesi brain-storming pada supervisor dan spesialis sistem terhadap fungsi manajemen pemesanan, termasuk daftar data pada database yang digunakan untuk prioritasi pesanan (Eccleson \& Jakfeld, 1992).

\subsection{User-Centered Design Approach}

Pengembangan berorientasi pada pengguna (User-centered approach / UCD) meliputi penemuan banyak hal tentang pengguna dan apa yang menjadi tugas atau pekerjaan mereka. Informasi yang diperoleh digunakan untuk mengembangkan desain/rancangan sistem yang akan dibuat. Cara terbaik dalam pengembangan adalah mengambil bagian dalam aktifitas pengguna untuk mengetahui kegiatan pengguna secara menyeluruh. Dengan cara ini, 
pengembang dapat mengerti dengan lebih baik kebutuhan dan tujuan akhir secara lebih tepat dan dapat menciptakan produk yang mampu pakai.

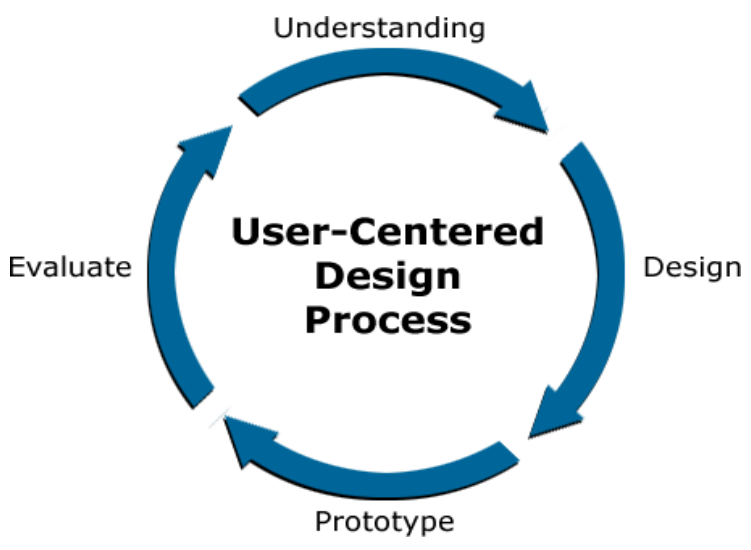

Gambar 1. Proses User-Centered Design

(Jess McMullin, User-Centered Origins: An outline of the User-Centered Design Process and the sources of current industry practices, 2000.)

Aspek penting lain dari pengembangan berorientasi obyek adalah mengikutsertakan pengguna dalam proses mengembangkan. Ada beberapa perbedaan tingkat keterlibatan pengguna, salah satunya adalah melakukan evaluasi akhir terhadap produk. Keterlibatan lain adalah pengguna berkontribusi aktif untuk merancang produk. Seperti yang dikatakan Gillian Crampton Smith, pengguna bukan perancang, tetapi merupakan sebuah keuntungan jika mengikutsertakan pengguna dalam perancangan produk sehingga penerimaan pengguna terhadap produk semakin baik (Preece et al., 2002: 198).

Landasan dasar pendekatan UCD adalah berfokus pada pengguna dan tugas sistem dengan cara mempelajari karakteristik kognitif, perilaku dan sikap pengguna. Secara empiris dapat diukur dengan melakukan pengamatan, mencatat dan menganalisa reaksi pengguna dan kinerja scenario, manual dan stereotype. (Preece et al., 2002).

Salah satu cara untuk menggunakan pengalaman dan pengetahuan pengguna secara efektif dalam perancangan adalah membuat maket produk. Teknik yang dapat digunakan adalah dengan paper-based prototyping. Teknik yang telah dikembangkan adalah Plastic Interface for Collaborative Technology Initiatives through Video ExIporation (PICTIVE) dan CARD (Preece et al., 2002).

\subsection{CARD (Collaborative Analysis of Requirement and Design)}

CARD adalah salah satu metode yang digunakan dalam User-Centered Design. Teknik ini banyak digunakan oleh programmer sebagai masukan untuk mendapatkan informasi struktur aplikasi. CARD mudah dilakukan, cepat, tidak terlalu mahal dan merupakan metode real yang 
banyak memberikan informasi dalam proses perancangan. CARD menghasilkan struktur aplikasi secara keseluruhan seperti menentukan rancangan tata letak navigasi, menu, dan taksonomi produk aplikasi, meskipun bukan merupakan suatu penyelesaian dalam suatu perancangan sistem. CARD melibatkan pengguna untuk menentukan struktur dan mengorganisasikan komponen aplikasi.

Menyerupai metode PICTIVE (Plastic Interface for Collaborative Technology Initiatives through Video Exlporation), yaitu penggunaan peralatan kontor seperti sticky note, pulpen, kertas untuk menggambarkan layout. CARD session dapat menggunakan format yang sama dengan PICTIVE session. Selama sesi perancangan pola pikir, memainkan kartu merupakan manipulasi oleh participant untuk memperlihatkan cara kerja layar komputer atau tujuan kerja mereka (Precee et al, 2002).

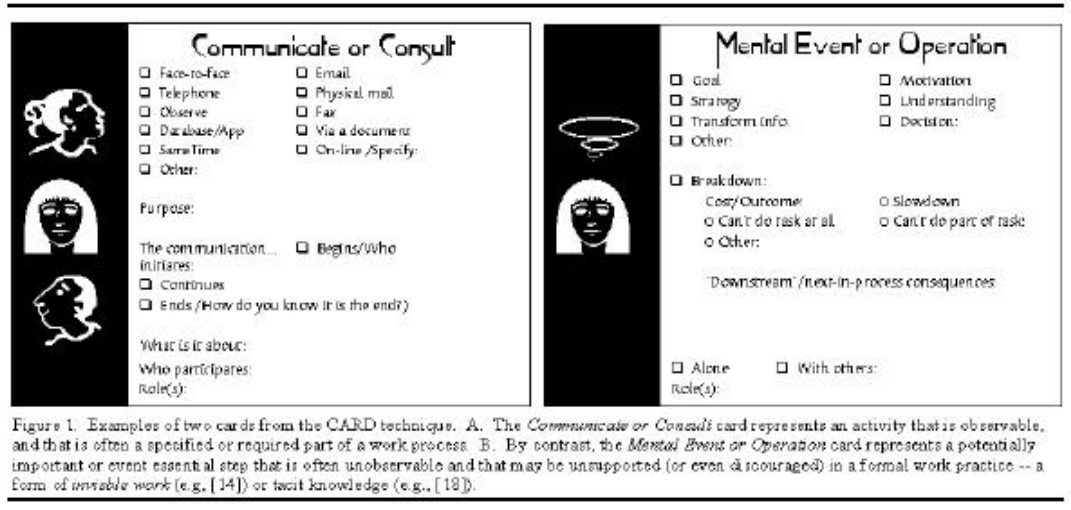

\section{Gambar 2. Contoh kartu}

(Muller, Layered Participatory Analysis: New Developments in the CARD Technique, http://www.infodesign.com.au/usabilityresources/cardsorting diakses 7 maret 2010)

Dalam penerapannya, menurut Spencer dan Warfel (2004) metode CARD dapat digunakan dengan cara :

- Open Card Sorting, pengguna diberikan kertas / kartu yang menunjukkan gambaran komponen. Tanpa mengawali untuk menginisialisasi kelompok komponen, pengembang dapat langsung menugaskan pengguna untuk menyusun kartu dalam kelompok yang mereka anggap sesuai untuk menggambarkan pengelompokan komponen. Cara ini sangat berguna dalam perancangan produk baru.

- Closed Card Sorting, pengguna diberikan kartu yang menunjukan gambaran komponen yang akan dipakai. Pengembang mengawali untuk membentuk kelompok primary komponen. Kemudian pengguna menyusun kartu pada primary group sesuai dengan keinginan dan kebutuhan mereka. Cara ini digunakan untuk 
menambah komponen pada aplikasi yang sudah jadi atau untuk mendapatkan feedback dari cara Open Card Sorting.

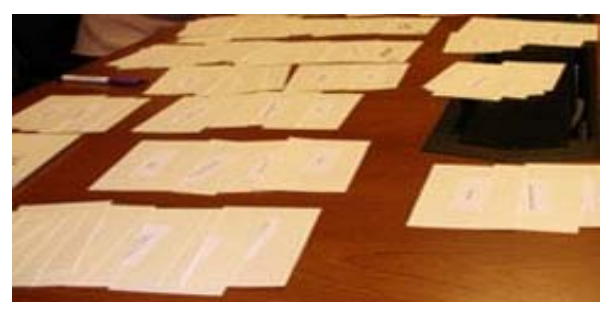

Gambar 3. Proses Kegiatan Cardsorting

Sumber : Spancer, D. \& Warfel, T. 2004. Card Sorting: A Definitive Guide

Proses percobaan tersebut akan berhenti pada saat kondisi jaringan kovergen yaitu output dari setiap unit (neuron) membentuk matriks yang setiap baris hanya ada satu unit yang bernilai 1 dan selebihnya bernilai 0 , dan setiap kolom hanya satu unit yang bernilai 1 dan selebihnya bernilai 0 . Pada saat kondisi jaringan konvergen maka dilakukan perhitungan energi jaringan keseluruhan. Nilai dari energi yang terkecil akan membentuk rute dengan jarak yang paling minimum.

\section{Perancangan Sistem}

Program bantu belajar yang akan dibuat berupa halaman pembelajaran dan halaman untuk latihan sebagai evaluasi pembelajaran bagi siswa didik. Proses perancangan program bantu pembelajaran dilakukan dalam beberapa tahap. Tahap pertama adalah pengumpulan data yang dilakukan dengan metode wawancara terhadap calon pengguna yang dalam hal ini adalah anak-anak penyandang cacat tuna daksa di Pusat Pehabilitasi Yakkum serta wawancara terhadap Ibu Sri Rumiati, Bapak Widodo dan Mas Kukuh selakau pengajar di unit pendidikan Yakkum. Selain dengan menggunakan metode wawancara, pengumpulan data juga dilakukan dengan observasi langsung terhadap kegiatan, proses belajar bagi anak cacat mampu didik di Pusat Rehabilitasi Yakkum dan kemampuan mereka baik dalam pengetahuan maupun kemampuan secara fisik. 


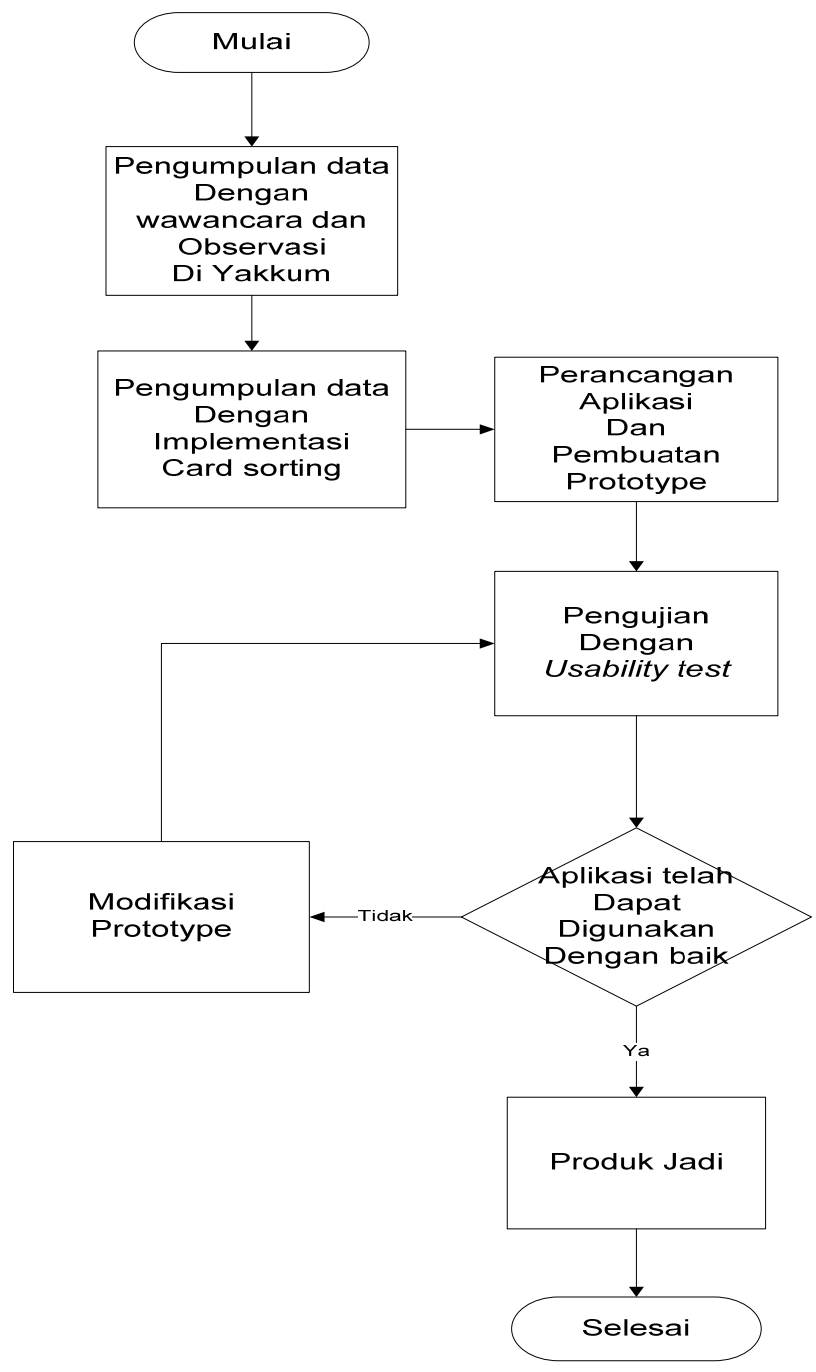

Gambar 4. Flowchar Perancangan Sistem

\section{Hasil dan Pembahasan}

Usability test menggunakan prototype. Pengujian dilakukan kepada siswa didik (peserta) di Pusat Rehabilitasi Yakkum. Usability test I yang dilakukan bertujuan untuk mengetahui pemahaman peserta terhadap aplikasi program bantu pembelajaran membaca. Kemampuan tersebut akan di nilai berdasarkan keberhasilan mengerjakan tugas (task). Tugas yang berhasil dilakukan dengan baik dan benar dalam waktu yang telah ditentukan diberi nilai 1 (berhasil) dan nilai 0 (gagal) jika peserta tidak berhasil melakukan tugas yang diminta atau salah melakukan tugas atau waktu yang digunakan untuk menyelesaikan tugas melebihi waktu maksimum (MTC) yang telah ditentukan dalam skenario.

Berdasarkan hasil pengujian terhadap aplikasi program bantu pembelajaran membaca didapat data sebagai berikut : 


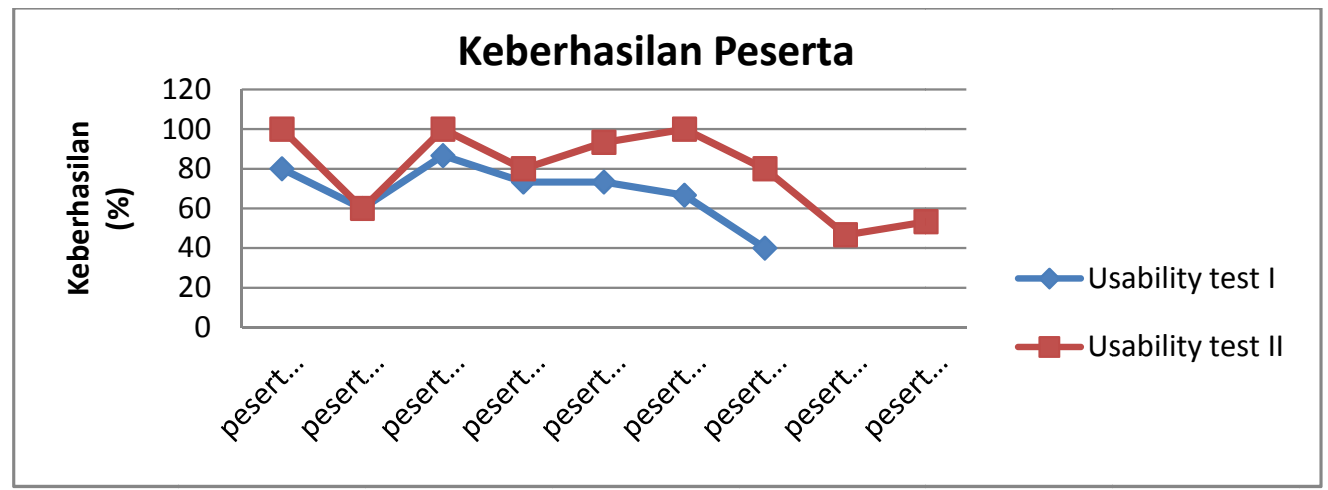

Gambar 5 Grafik Keberhasilan Test pada Siswa Didik

Pengujian yang dilakukan terhadap usability sistem memberikan hasil sebagai berikut.

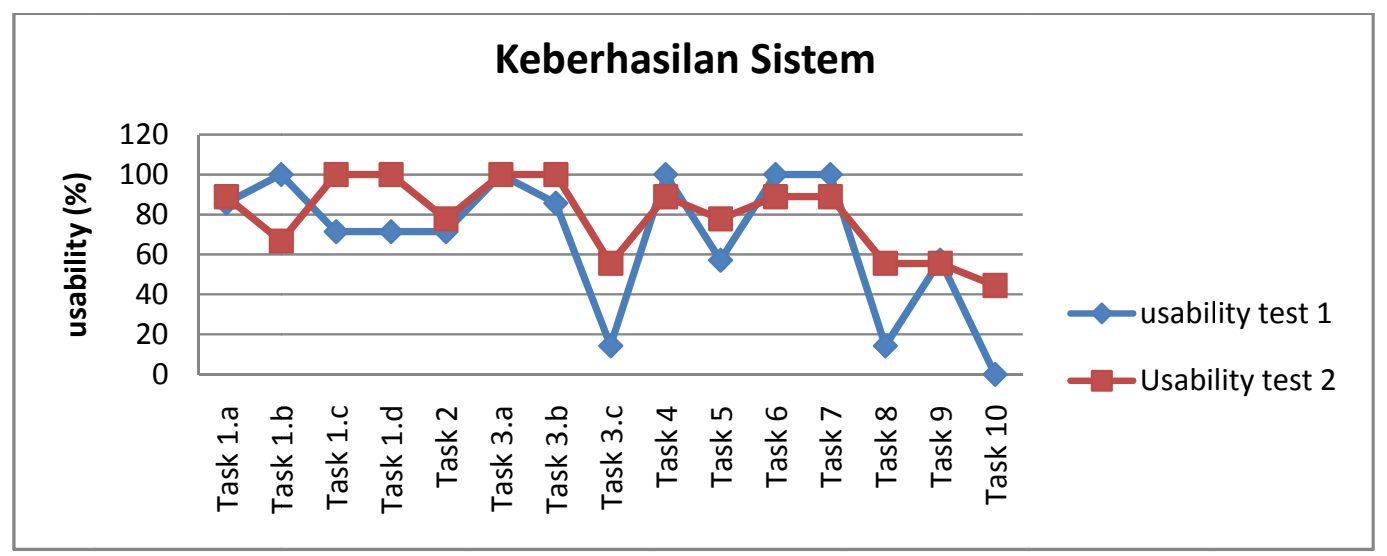

Gambar 6 Grafik Keberhasilan Test pada Sistem

Dalam tahap pengujian dilakukan pula uji preferensi peserta terhadap aplikasi program bantu pembelajaran membaca ini. Berdasarkan pengujian wawancara terhadap peserta uji didapatkan hasil uji preferensi seperti ditunjukan pada grafik berikut.

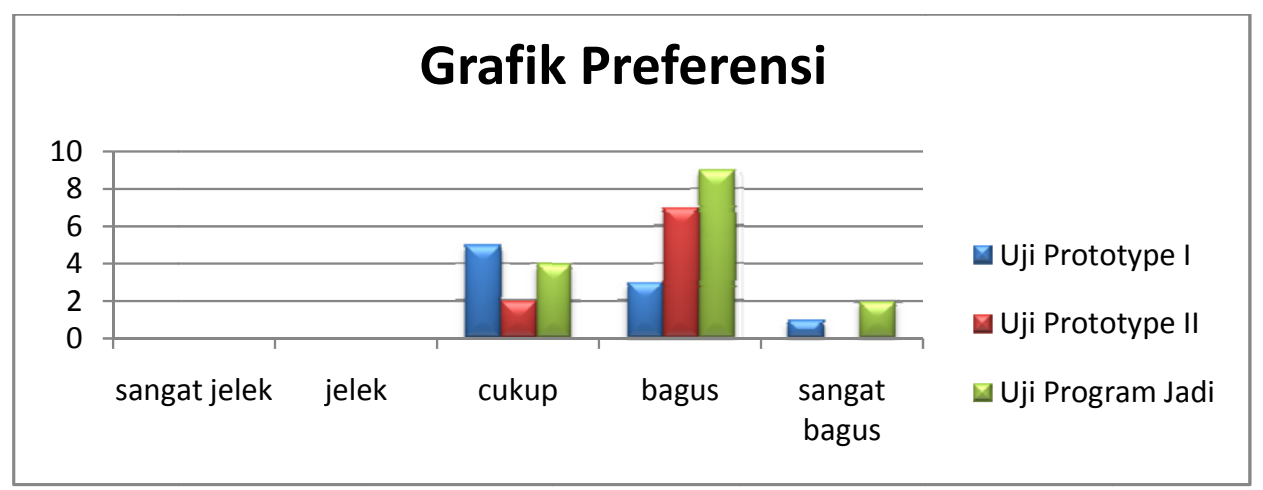

Gambar 7 Grafik Preferensi Peserta Uji

Peserta uji mayoritas menyatakan program bantu pembelajaran ini baik digunakan 
untuk belajar baik secara mandiri maupun dengan pendampingan oleh pengajar. Selain mudah digunakan program bantu ini menarik sehingga memicu pengguna untuk belajar dengan menggunakan aplikasi program bantu pembelajaran ini.

\section{Kesimpulan dan Saran}

Dari hasil penelitian yang dilakukan penulis terhadap Implementasi CARD dalam Perancangan Program Bantu Pembelajaran Membaca dapatlah ditarik beberapa kesimpulan. Pertama, aplikasi yang dibangun berdasarkan metode CARD tersebut dapat menghasilkan program bantu pembelajaran dasar pengenalan huruf, kata dan kalimat. Kedua, antarmuka yang dihasilkan dari tahap implementasi CARD memberikan kemudahan bagi pengguna serta dipahami secara khusus oleh pengguna di Yakkum. Berdasarkan hasil pengujian, implementasi metode CARD dapat menghasilkan rangkaian kegiatan yang mudah dipahami oleh pengguna serta disesuaikan dengan kebutuhan pengguna di Yakkum.

\section{Daftar Pustaka}

[1] Darudiarto, S. (2006). Analisis dan perancangan aplikasi perangkat ajar berbasis multimedia dengan studi kasus: mata kuliah analisa \& perancangan sistem informasi. Seminar Nasional Sistem dan Informatika 2006; Bali, November 17, 2006. Diakses dari http://yudiagusta.files.wordpress.com/2009/11/227-234-snsi06-37-analisis-danperancangan-aplikasi-perangkat-ajar-berbasis-multimedia.pdf

[2] Eccleson, P., Jakfeld, C. (1992). The application of a modified card sort in the creation of an order management knowledge-base. Diakses dari http://www.hpl.hp.com/techreports/92/HPL-92-76.pdf

[3] Faiks, A., Hyland, N. (2000). Gaining user insight: a case study illustrating the card sort technique. Diakses dari http://crl.acrl.org/content/61/4/349.full.pdf+html

[4] Hasanuddin. (2006). Pelayanan olahraga adaptif bagi tunadaksa cerebral palsy pada poliklinik fisioterapi badan pengelola rsud dokter soeselo kabupaten tegal. Skripsi S1 Semarang : Jurusan IImu Keolahragaan, Fakultas IImu Keolahragaan, Universitas Negeri Semarang. Diakses dari http://digilib.unnes.ac.id/gsdl/collect/skripsi/archives/HASH0142/6faad5c3.dir/doc.pdf

[5] McMullin, J. (2000). User-centered origins: an outline of the user-centered design process and the sources of current industry practices. Diakses dari http://www.interactionary.com/files/ucd class.pdf

[6] Muller, M. J. (2001). Layered participatory analysis : new developments in the card technique. Diakses dari http://domino.research.ibm.com/cambridge/research.nsf/0/7a84eb8a352454c8852569b c00551911/\$FILE/p13-muller.pdf

[7] Nurmuliani, N., et al., (2004). Using card sorting technique to classify requirements 
change. Diakses dari

http://www.computer.org/portal/web/csdl/doi/10.1109/ICRE.2004.1335681

[8] Preece, Rogers, Sharp. (2002). Interaction design: beyond human-computer interaction. John Wiley \& Sons, Inc, Canada.

[9] Rubin, J. (1994). Handbook of usability testing : how to plan, design, and conduct effective test. John Wiley \& Sons, Inc., Canada.

[10] Santosa, I. (1997). Interaksi manusia dan komputer: Teori dan praktek. ANDI Offset, Yogyakarta.

[11] Saputra, D.A. (2009). Game animasi platform untuk pembelajaran operasi bilangan. Skripsi S1, Yogyakarta : Program Studi Teknik Informatika, Fakultas Teknik, Universitas Kristen Duta Wacana Yogyakarta.

[12] Spencer, D. \& Warfel, T. (2004). Card sorting: a definitive guide. Diakses dari http://www.boxesandarrows.com/view/card sorting a definitive guide 